\title{
Gerakan Masyarakat Kendeng, Rembang untuk Keadilan dan Penegakan Hak Asasi Manusia
}

\author{
Rizky Agus Harnanto, ${ }^{1}$ Atika Ishmatul Ummah, ${ }^{2}$ Elsya Rekavianti, ${ }^{3}$ \\ Ayu Ratnasari ${ }^{4}$ \\ Universitas Islam Negeri Walisongo, Semarang \\ (e-mail: 1harnantorizky@gmail.com; 2atikaishmatul@yahoo.com; \\ 3elsyareka14@gmail.com; ${ }^{3}$ ayuratnasari704@gmail.com)
}

\begin{abstract}
The case of injustices and human rights violations in Kendeng, Rembang Regency become a national issue that has led to the emergence of the social movement to defend the rights of people. LBH Semarang is among CSOs that actively engage in the movement. This research is qualitative and descriptive using LBH Semarang as a case study. By applying observation, interviews and document study, this research found that LBH Semarang Plays important role in organizing the movement to reject the establishment of cement industry in Kendeng.
\end{abstract}

Kasus ketidakadilan dan pelanggaran HAM di Kendeng, Kabupaten Rembang menjadi isu nasional yang mendorong munculnya gerakan sosial untuk membela hak-hak rakyat. LBH Semarang adalah salah satu organisasi sosial yang aktif terlibat dalam gerakan ini. Penelitian ini adalah kualitatif dan deskriptif dengan menggunakan LBH Semarang sebagai studi kasus. Dengan menerapkan observasi, wawancara dan studi dokumen, penelitian ini menemukan bahwa LBH Semarang memainkan peran penting dalam mengorganisir gerakan untuk menolak pendirian industri semen di Kendeng.

Keywords: lembaga bantuan hukum; gerakan sosial; Pegunungan Kendeng 


\section{Pendahuluan}

Beberapa isu pelanggaran Hak Asasi Manusia (HAM) telah terjadi di Indonesia. Salah satunya terkait isu lingkungan yakni kasus pembangunan pabrik semen di kawasan Pegunungan Kendeng, Kabupaten Rembang, Provinsi Jawa Tengah. Kasus tersebut melibatkan PT. Semen Indonesia dengan warga kawasan Pegunungan Kendeng. Dalam kasus tersebut disinyalir terjadi ketimpangan dalam penegakan hukum yang adil tersebut tak kunjung dapat terselesaikan. Warga merasa dirugikan akibat pembangunan pabrik dan menuntut pemerintah untuk menutup pembangunan pabrik tersebut, namun belum dilaksanakan oleh pemerintah. Berbagai upaya dilakukan warga, salah satunya melakukan gerakan sosial untuk menolak pembangunan pabrik semen tersebut. Keterbatasan pengetahuan warga dalam menyelesaikan kasus yang kaitannya dengan keadilan hukum dan HAM membuat warga berinisiatif untuk mencari bantuan hukum dalam upaya menuntut keadilan.

Bantuan hukum merupakan upaya untuk membantu orang yang tidak mampu dalam bidang hukum. Penyedia bantuan hukum merupakan aktivitas derma bagi pemenuhan rasa peri kemanusiaan. Namun, bantuan hukum berkembang bukan sekedar aksi kedermawanan namun bagian dari pemenuhan hak warga. Dinamika gerakan bantuan hukum di Indonesia sudah ditemui pada masa pra kemerdekaan. Namun, pada dekade 1970-an, menunjukkan bahwa bantuan hukum me- rupakan bagian dari manifestasi fungsi dan peran advokat dalam membela Hak Asasi Manusia (HAM) dengan memberi bantuan hukum kepada masyarakat yang kurang mampu dan lemah. Orientasi bantuan hukum yang semakin berkembang, tidak lagi sekedar menegakkan keadilan bagi si miskin, namun juga berusaha mewujudkan negara hukum yang berlandaskan prinsip demokrasi dan HAM (Triwibowo 2006: 155-159).

Dalam perkembangannya, aktivitas bantuan hukum diwadahi suatu organisasi Lembaga Bantuan Hukum (LBH). LBH melakukan gerakan sosial dengan mengembangkan strategi sebagai penyedia bantuan hukum bagi masyarakat untuk mendapatkan pemenuhan hak-haknya di depan hukum. LBH dengan pendekatan bantuan hukum struktural, yakni pendekatan yang bertujuan untuk menciptakan kondisi-kondisi bagi terwujudnya hukum yang mampu mengubah struktur yang timpang menuju keadilan dan persamaan, mulai memainkan peran sentral dalam perkembangan gerakan bantuan hukum di Indonesia.

Peran LBH dalam menegakkan keadilan hukum dan HAM melingkupi peran advokat, penolong, dan organisatoris. LBH tidak hanya melakukan pendampingan terhadap kasus keadilan hukum dan HAM, namun juga mulai membangun kesadaran kritis masyarakat akan hak untuk mendapatkan bantuan hukum serta memberikan alternatif untuk tidak bergantung pada inisiatif negara. LBH kadang sangat kritis terhadap pemerintah dan tidak hanya terjebak dalam bantuan hukum konvensional. Meningkatnya kesadaran tersebut 
pada akhirnya berkorelasi dengan meningkatnya kebutuhan akan pemenuhan hak (Triwibowo 2006: 163-167).

Dalam menghadapi dinamika masalah hukum dan HAM yang berkembang dalam suatu masyarakat, peran LBH sangat penting. Peran LBH dalam menegakkan keadilan hukum dan HAM melingkupi peran sebagai advokat, penolong, dan organisatoris. Kunci penting keberhasilan merupakan strategi yang digunakan LBH Semarang dalam gerakan sosial menolak pembangunan pabrik semen di kawasan Pegunungan Kendeng.

LBH Semarang merupakan BHS (Bantuan Hukum Struktural). Bantuan hukum struktural merupakan satu metode bantuan hukum yang mendasarkan pada pembacaan situasi struktural baik itu politik, ekonomi, sosial maupun budaya. Banyaknya masyarakat yang membutuhkan bantuan hukum mendorong BHS memberikan bantuan hukum secara gratis bagi korban ketidakadilan, membela tanpa membedakan jenis kelamin, agama, suku, etnis dan keyakinan politik.

Berangkat dari realitas tersebut, penelitian ini berupaya mendeskripsikan mengenai peran LBH Semarang dalam upaya untuk memberikan bantuan hukum kepada masyarakat dengan berbagai persoalan yang dihadapinya khususnya peran LBH Semarang dalam mendorong lahirnya gerakan sosial untuk menolak pembangunan pabrik semen di kawasan Pegunungan Kendeng. Di balik peran tersebut juga dijelaskan hambatan dan tantangan yang dihadapi LBH Semarang bersama warga kawasan Pegunungan Kendeng dalam gerakan sosial untuk menolak pembangunan pabrik semen di kawasan tersebut. Adanya temuantemuan dalam penelitian ini dapat menjadi masukan bagi semua kalangan tentang bagaimana upaya menegakan keadilan hukum dan HAM.

Penelitian tentang gerakan sosial untuk menolak pembangunan pabrik semen di kawasan pegunungan Kendeng telah banyak dilakukan beberapa penelitian tersebut di antaranya pertama, dalam jurnal berjudul "Gerakan Sosial Masyarakat Pegunungan Kendeng Utara Melawan Pembangunan Pabrik Semen di Kabupaten Rembang" karya Ahmad Sufyani (2015) dari Universitas Airlangga. Dalam karya tersebut menjelaskan bahwa dalam gerakan sosial Kabupaten Pati, penularan sikap menolak di Kabupaten Rembang. Akan tetapi, penularan yang terjadi dikarenakan adanya aktor gerakan yang ikut dalam kasus di Kabupaten Rembang. Gerakan sosial masyarakat Pegunungan Kendeng Utara merupakan gerakan sosial masyarakat yang bersifat sparatis. Gerakan tersebut mencerminkan usaha masyarakat sipil yang melawan kekuatan modal. Gerakan sosial masyarakat tersebut mencapai keberhasilan ketika mampu melakukan aksi pemblokiran pabrik semen (Sufyani 2015).

Kedua penelitian "Gerakan Sosial Perempuan Ekofeminisme di Pegunungan Kendeng Provinsi Jawa Tengah Melawan Pembangunan Tambang Semen" karya Annisa Innal Fitri dan Idil Akbar dari Departemen Ilmu Pemerintahan Fakultas Ilmu Sosial dan Ilmu Politik Universitas Padjadjaran. Dalam penelitian ini 
menjelaskan bahwa gerakan sosial perempuan yang dihadirkan sejak awalnya merupakan suatu usaha untuk mengangkat posisi perempuan. Ini berangkat dari asumsi bahwa peran perempuan dalam kehidupan masyarakat atau ranah kebijakan publik di berbagai belahan dunia dari waktu ke waktu terus berkembang, khususnya di Indonesia. Perkembangan ini tentunya mengarah kepada terciptanya ruang yang memberikan kesetaraan bagi perempuan baik secara individual maupun perempuan sebagai komponen masyarakat.

Ayu Ratih, seorang aktivis buruh perempuan, mendefenisikan gerakan perempuan sebagai usaha untuk menerobos batasan yang memisahkan persoalan ketertindasan perempuan dan ketertindasan manusia secara keseluruhan. Ini berarti gerakan perempuan harus menyusun strategi tentang bagaimana memberi warna perempuan pada setiap gerakan pembebasan yang bertujuan untuk menghapuskan segala bentuk diskriminasi dan ketidaksetaraan dalam hubungan antar manusia yang beradab. Dalam kasus Pabrik Semen Rembang, para perempuan telah mewujudkan responnya dalam bentuk gerakan sosial melawan tambang pabrik semen, mereka merasa memiliki hak sebagai masyarakat sipil untuk mengemukakan pendapatnya sebagai input suatu kebijakan sosial (Fitri dan Akbar 2017).

Ketiga, penelitian berjudul "Resolusi Konflik Pendirian Pabrik Semen Antara PT. Sahabat Mulia Sakti dengan Masyarakat di Kabupaten Pati Tahun 2015 (Studi Kasus: Peran Jaringan
Masyarakat Peduli Pegunungan Kendeng)". yang menjelaskan tentang proses pembangunan yang dilakukan seringkali tidak tepat sasaran karena pemerintah kurang responsif terhadap kebutuhan masyarakat. Oleh karena itu, dalam konflik pabrik semen antara masyarakat dengan PT. Sahabat Mulia Sakti, Pemerintah Daerah Kabupaten Pati harus peka terhadap permasalahan yang dialami masyarakatnya. Apabila masyarakat kontra bersikukuh bahwa pabrik semen akan memberikan lebih banyak dampak negatif terhadap kondisi sosial ekonomi, budaya dan politik, maka pemerintah sebagai pemegang kekuasaan harus mampu mencari solusi alternatif sebagai pondasi jangka panjang untuk kemajuan dan kesejahteraan rakyat Pati (Sinduprabowo 2017).

Pemanfaatan sumber daya alam yang dikelola Pemerintah Daerah harus dilaksanakan secara adil dan selaras. Jika tidak demikian, maka yang akan terjadi adalah konflik. Masyarakat di Pati Selatan, khususnya di Kecamatan Tambakromo, Kayen dan Sukolilo tidak menginginkan adanya perubahan yang mempengaruhi sistem tata sosial dan budayanya. Sedangkan pihak pro akan terus memberikan dukungan kepada investor agar dapat mendirikan pabrik semen di Kecamatan Tambakromo dan Kayen untuk memanfaatkan tanah kars Pegunungan Kendeng sebagai bahan baku semen dan bisa memberikan lapangan kerja kepada penduduk sekitar calon lokasi pabrik, sehingga dampak positif dari pembangunan daerah dapat mewujudkan masyarakat yang sejahtera (Sinduprabowo 2017). 
Untuk menjawab persoalan penelitian sebagaimana telah diuraikan peneliti menggunakan jenis penelitian deskriptif kualitatif studi kasus. Penelitian ini menekankan pada data yang digali di lapangan dengan teknik tertentu, kemudian diilustrasikan dalam kalimat dengan mengkategorikan berdasarkan karakter tertentu kemudian diambil kesimpulan.

Untuk menggali data secara mendalam dan komprehensif, peneliti menggunakan beberapa tehnik pengumpulan data, meliputi: 1) Observasi yaitu pengamatan yang melibatkan pencatatan hasil dari penelitian yang dapat dilakukan secara sistematis dan sengaja yang dilakukan melalui pengamatan dan pencatatan gejala-gejala yang diteliti. 2) Interview (wawancara) dilakukan dengan secara langsung dengan sumber datanya yaitu, pengurus LBH Semarang dan masyarakat Pegunungan Kendeng Rembang. Wawancara dilakukan melalui tatap muka untuk bertukar informasi dan ide melalui tanya jawab, sehingga dapat dikonstruksikan makna dalam suatu topik tertentu. 3) Dokumentasi merupakan pengambilan data melalui dokumen tertulis maupun elektronik dari pihak, lembaga atau institusi yang bersangkutan. Dokumen diperlukan untuk mendukung kelengkapan data yang lain dengan cara mengumpulkan berbagai dokumen yang kaitannya dengan masalah yang diteliti.

Proses pengolahan data agar dapat disajikan, dianalisis dan diinterpretasikan secara lebih baik, maka digunakan melalui teknik analisis data dengan cara menekankan analisa atau penilaian secara mendalam terhadap data yang diperoleh di lapangan. Untuk selanjutnya diterjemahkan melalui perspektif peneliti, tanpa merubah esensi atau makna dari data yang diperoleh, sehingga akan lebih efektif dan efisien.

Dalam penelitian ini peneliti menggunakan teori tentang LBH, keadilan, hukum dan HAM. Sugiyono menyatakan bahwa landasan teori perlu ditegakkan agar penelitian itu mempunyai dasar yang kokoh, dan bukan sekedar perbuatan coba-coba (Sugiyono 2005: 55). Dalam penelitian ini yang menjadi landasan teorinya adalah sebagai berikut:

\section{Gerakan Sosial}

Gerakan sosial lahir dari situasi dalam masyarakat karena adanya ketidakadilan dan sikap sewenang-wenang terhadap masyarakat. Gerakan sosial lahir dari reaksi terhadap sesuatu yang tidak diinginkan rakyat atau menginginkan perubahan kebijakan karena dinilai tidak adil. Gerakan sosial merupakan gerakan yang lahir dari prakarsa masyarakat dalam menuntut perubahan dalam institusi, kebijakan atau struktur pemerintahan. Disini terlihat tuntutan perubahan itu lahir karena melihat kebijakan yang ada tidak sesuai dengan konteks masyarakat yang ada maupun bertentangan dengan kepentingan masyarakat scara umum. Nelson A. Pichardo, mengatakan bahwa paradigma gerakan sosial merupakan cerminan dari karakter kelas, karena ia dapat menunjukkan segala apa yang kelas inginkan. Menurut Keun, mobilisasi terhadap partisipan itu dapat dilakukan melalui mobilisasi personal maupun mobilisasi kognitif. Dalam hal 
ini, gerakan sosial yang diinisiasi oleh jaringan organisasi merupakan gerakan sosial yang memiliki tujuan yang sama untuk melakukan perlawanan terhadap penguasa dan perusahaan (Wahyudi 2005: 8).

Seiring perkembangan kisah-kisah gerakan sosial yang makin beraneka ragam, tidak ada definisi tunggal mengenai konsep gerakan sosial sebagai suatu gejala sosial. Giddens mendefinisikan gerakan sosial sebagai suatu upaya kolektif untuk mengejar suatu kepentingan bersama, atau mencapai tujua bersama melalui tindakan kolektif (collective action) diluar lingkup lembaga-lembaga yang mapan. Definisi senada dirumuskan oleh seorang teoritisi terkemuka, Sydney Tarrow yang mengungkapkan bahwa gerakan sosial adalah tantangan-tantangan kolektif yang didasarkan pada tujuan-tujuan bersama dan solidaritas sosial, dalam interaksi yang berkelanjutan dengan para elit, penentang dan pemegang wewenag. Dari dua definisi, gerakan sosial merupakan gerakan kolektif yang bersifat menentang untuk mencapai tujuan kolektif pula (Suharko 2006: 3).

Gerakan sosial memiliki bentuk atau isu yang beragam. Gerakan sosial bisa memiliki partisipan yang sangat sedikit hingga ribuan bahkan jutaan orang. Gerakan sosial bisa pula beroperasi dalam batas-batas legalitas suatu masyarakat, namun bisa juga bergerak secara ilegal atau sebagai kelompok 'bawah tanah' (underground groups). Tarrow mengungkapkan konsep gerakan sosial memilik beberapa sarana dan prasarana dasar, salah satunya yaitu membentuk solidaritas dan identitas kolektif. Sesuatu yang menggerakan secara bersama-sama (common denominator) dari gerakan sosial adalah pertimbangan partisipan tentang kepentingan bersama yang kemudian mengantarai perubahan dari sekedar potensi gerakan menjadi aksi nyata. Dengan cara menggerakan konsensus, perancang gerakan memainkan peran penting dalam merangsang munculnya konsesus semacam itu. Namun, para pemimpin hanya dapat menciptakan suatu gerakan sosial ketika mereka menggali lebih dalam sisi perasaan solidaritas atau identtas, yang biasanya bersumber dari nasionalisme, ennisitas atau keyakinan agama.

Selain itu, sarana prasana dasar lain yang ditawarkan oleh Tarrow, dengan memelihara politik perlawanan. Hanya dengan cara memelihara aksi kolektif melawan pihak musuh, suatu episode perlawanan bisa menjadi gerakan sosial. Tujuan kolektif, identitas bersama, dan tantangan yang dapat diidentifikasi. Membantu gerakan untuk memelihara politik perlawanan ini. Sebaliknya, jika mereka tidak mampu memelihara tantangan bersama, maka gerakan mereka akan menguap menjadi semacam kebencian atau kemarahan individual, atau berubah menjadi sekte religius, atau mungkin menarik diri ke dalam isolasi. Karena itu, memelihara aksi kolektif dalam interaksi dengan pihak lawan yang kuat menandai titik pergeseran dimana suatu penentangan (contention) berubah menjadi suatu gerakan sosial (Suharko 2006: 3-7).

\section{Keadilan Hukum dan HAM}

Dalam penelitian ini, peneliti mengaitkan keadilan dalam proses hukum. Menurut 
Thomas Hobbes keadilan adalah setiap perbuatan yang dikatakan adil. Keadilan hanya tercipta ketika apa yang dikerjakan telah sesuai dengan perjanjian yang telah dibuat atau pun disepakati sebelumnya. Sedangkan keadilan berdasarkan undang-undang disebut sebagai keadilan legal (Iustitia Legalis). Yang menjadi objek dari keadilan legal adalah tata masyarakat. Tata masyarakat itu dilindungi oleh undang-undang. Tujuan keadilan legal adalah terwujudnya kebaikan bersama (banum commune). Keadilan legal terwujud ketika warga masyarakat melaksanakan undang-undang, dan penguasa pun setia melaksanakan undang-undang itu.

Hukum itu sendiri dijelaskan oleh J.C.T. Simorangkir, SH dan Woerjono Sastropranoto, SH bahwa hukum adalah peraturan-peraturan yang bersifat memaksa, yang menentukan tingkah laku manusia dalam lingkungan masyarakat yang dibuat oleh badan-badan resmi yang berwajib. Sedangkan menurut Immanuel Kant hukum ialah keseluruhan syarat-syarat yang dengan ini kehendak bebas dari orang yang satu dapat menyesuaikan dengan kehendak bebas dari orang lain, menuruti peraturan hukum tentang kemerdekaan (Arrasjid 2000: 21).

Menururt A. Mansyur Effendi, hak asasi manusia (HAM) sering di sebut juga sebagai hak kodrat, hak dasar manusia, hak mutlak atau dalam bahasa Inggris di sebut natural rights, human rights dan fundamental rights. Dalam UU No. 39 Tahun 1999 tentang HAM disebutkan bahwa hak asasi manusia adalah seperangkat hak yang melekat pada hakikat dan keberadaan manusia sebagai makhluk
Tuhan YME dan merupakan anugerah-Nya, yang wajib dihormati, dijunjung tinggi, dan dilindungi oleh negara, hukum, pemerintah, dan setiap orang demi kehormatan serta perlindungan harkat dan martabat manusia (Qomar 2016: 15).

Macam-macam hak asasi manusia sebagai warga negara dalam berbangsa dan bernegara, yaitu: 1) Civil rights, yang meliputi kemerdekaan memeluk agama, beribadat menurut agama masing-masing, menyatakan pendapat, dan kebebasan bergerak. 2) Socio economic rights, yang meliputi hak dan kebebasan memiliki sesuatu, hak membeli dan menjual sesuatu, dan hak mengadakan sesuatu perjanjian atau kontrak. 3) Political rights, yang meliputi hak ikut serta dalam pemerintahan, hak pilih dalam pemilu, hak mendirikan partai politik. 4) Cultural rights, yang meliputi hak mendapatkan pengajaran dan hak mengembangkan kebudayaan (Arrasjid 2000: 96).

\section{Lembaga Bantuan Hukum (LBH)}

LBH lahir karena adanya sebuah tujuan dalam membantu masyarakat yang tidak mampu baik secara ekonomi maupun kedudukan strata sosial. Selain itu terdorong karena keinginan dalam penegakkan keadilan dan kedudukan yang sama di depan hukum. Menurut Adnan Buyung Nasution bantuan hukum adalah Legal aid, yang berarti pemberian jasa di bidang hukum kepada seseorang yang terlibat dalam suatu kasus atau perkara, meliputi: 1) Pemberian jasa bantuan hukum dilakukan dengan cuma-cuma. 2) Bantuan jasa hukum dalam legal aid lebih dikhususkan bagi yang tidak mampu dalam lapisan masyarakat 
miskin, 3) Dengan demikian motivasi utama konsep legal aid adalah menegakkan hukum dengan jalan membela kepentingan hak asasi rakyat kecil dan buta hukum (Nasution 2007: 13).

Dalam keputusan menteri kehakiman No.M.01.U.M.08.10. tanggal 13 Oktober 1981 tentang petunjuk pelaksanaan proyek konsultasi dan bantuan hukum melalui fakultas hukum negeri. Pada pasal 2 dijelaskan bahwa, "Bantuan hukum diberikan kepada klien terhadap perkara pidana maupun perkara perdata yang diajukan pada badan peradilan atau badan-badan lain yang memberikan peradilan, sejak awal sampai diperolehnya keputusan yang telah mendapatkan kekuatan hukum yang pasti dan melalui kegiatankegiatan mewakili klien sebagai kuasa khusus dimuka badan peradilan"

Lembaga bantuan hukum atau legal aid adalah segala bentuk bantuan hukum (baik bentuk pemberian nasehat hukum, maupun yang berupa menjadi kuasa daripada seseorang yang berperkara) yang diberikan kepada orang yang tidak mampu ekonominya, sehingga ia tidak dapat membayar biaya (honorarium) kepada seorang pembela atau pengacara.

Daniel S Lev mengkategorikan pengacara LBH sebagai advokat aktivis karena juga berjuang dalam perubahan. Lembaga Bantuan Hukum banyak didirikan di kantor-kantor pengadilan atau setiap pos-pos di lingkungan sekitar masyarakat. Tujuannya agar setiap keluhan dan laporan masyarakat langsung bisa ditampung dan dilayani. Fungsi dan peran LBH adalah: 1) Public service. Sehubungan dengan kondisi sosial ekonomi karena sebagian besar dari masyarakat kita tergolong tidak mampu atau kurang mampu untuk menggunakan dan membayar jasa advokat, maka Lembaga Bantuan Hukum memberikan jasa-jasanya dengan cuma-cuma. 2) Social education. Sehubungan dengan kondisi sosial kultural, dimana lembaga dengan suatu perencanaan yang matang dan sistematis serta metode kerja yang praktis harus memberikan peneranganpenerangan dan petunjuk-petunjuk untuk mendidik masyarakat agar lebih sadar dan mengerti hak-hak dan kewajiban-kewajibannya menurut hukum. 2) Perbaikan tertib hukum. Sehubungan dengan kondisi sosial politik, dimana peranan lembaga tidak hanya terbatas pada perbaikan-perbaikan di bidang peradilan pada umumnya, pada profesi pembelaan khususnya, akan tetapi juga dapat melakukan pekerjaan-pekerjaan Ombudsman selaku partisipasi masyarakat dalam bentuk kontrol dengan kritik-kritik dan saran-sarannya untuk memperbaiki kepincangan-kepincangan atau mengoreksi tindakan-tindakan penguasa yang merugikan masyarakat. 3) Pembaruan hukum. Dari berbagai pengalaman praktis dalam melaksanakan fungsinya lembaga menemukan banyak sekali peraturan-peraturan hukum yang sudah usang tidak memenuhi kebutuhan baru, bahkan kadang-kadang bertentangan atau menghambat perkembangan keadaan. Lembaga dapat mempelopori asulusul perubahan undang-undang. 4) Pem- 
bukaan lapangan kerja (labour market). Berdasarkan kenyataan bahwa dewasa ini tidak terdapat banyak pengangguran sarjana-sarjana hukum yang tidak atau belum dimanfaatkan atau dikerahkan pada pekerjaan-pekerjaan yang relevan dengan bidangnya dalam rangka pembangunan nasional. Lembaga Bantuan Hukum jika saja dapat didirikan di seluruh Indonesia misalnya satu kantor Lembaga Bantuan Hukum, di setiap ibu kota kabupaten, maka banyak sekali tenaga sarjana-sarjana hukum dapat ditampung dan di manfaatkan. 5) Practical training. Fungsi terakhir yang tidak kurang pentingnya bahkan diperlukan oleh lembaga dalam mendekatkan dirinya dan menjaga hubungan baik dengan sentrumsentrum ilmu pengetahuan adalah kerjasama antara lembaga dan fakultas-fakultas hukum setempat. Kerjasama ini dapat memberikan keuntungan kepada kedua belah pihak. Bagi fakultas-fakultas hukum lembaga dapat dijadikan tempat lahan praktek bagi para mahasiswa hukum dalam rangka mempersiapkan dirinya menjadi sarjana hukum yang dapat menguji teori-teori yang dipelajari dengan kenyataan dan kebutuhan dalam praktek dan dengan demikian sekaligus mendapatkan pengalaman (Hakim dan Kusuma 1981: Hakim).

\section{Peran LBH Semarang dalam Gerakan Sosial Penolakan Pembangunan Pabrik Semen di Pegunungan Kendeng}

LBH Semarang mengkonsentrasikan bantuan hukumnya pada penanganan kasus-kasus struktural yang berbasis pada beberapa isu, seperti pertanahan dan lingkungan hidup, perburuhan, kebijakan kota atau masyarakat miskin kota dan masyarakat pesisir/nelayan. Isu tersebut di-back-up dalam rangka pemenuhan, penghormatan dan perlindungan hak-hak sipil dan politik serta ekonomi, sosial dan budaya. Langkah ini dilakukan melalui proses litigasi (penanganan kasus) dan non litigasi (pendidikan dan pengorganisasian). Sebagai tahapan pencapaian tujuan dan untuk menjawab kendala yang sesuai dengan kondisi politik, ekonomi, sosial dan budaya ditingkat lokal maka setiap 3 tahun diselenggarakan perencanaan strategis.

LBH Semarang secara umum melakukan gerakan sosial penanganan kasus pelanggaran HAM tidak hanya melalui pendampingan hukum dalam proses persidangan saja melainkan juga melakukan pemberdayaan berupa pendidikan dan sekaligus pengorganisasian hukum dalam setiap kasus yang ditangani. Berikut beberapa pola gerakan yang dilakukan LBH Semarang: 1) Bantuan Hukum Struktural (BHS). 2) Layanan Bantuan Hukum. 3) Pendidikan dan pengorganisasian. 4) Advokasi kebijakan (LBH Semarang n.d.).

Fenomena penolakan petani di Kendeng terhadap PT. Semen Indonesia termasuk dalam kategori gerakan sosial baru. Karena bentuk penolakan ini didasari oleh masalah lingkungan. Sesuai dengan UU No. 32 Tahun 2009 tentang perlindungan dan pengelolaan lingkungan hidup menyebutkan bahwa masyarakat memiliki hak dan kesempatan berperan aktif dalam melindungi dan mengelola lingkungan hidup. 
Berdasarkan hasil wawancara dengan Ngatiban, ${ }^{1}$ sejak munculnya isu akan adanya pembangunan pabrik semen pada akhir tahun 2012, warga kawasan Pegunungan Kendeng, terutama Desa Tegaldowo berusaha mencari kejelasan atas isu tersebut mulai dari kepala desa, pemerintah tingkat kecamatan hingga kabupaten untuk menanyakan isu pembangunan pabrik semen. Namun, tidak ada kejelasan yang didapatkan oleh warga.

Berangkat dari permasalahan tersebut, warga berinisiatif untuk mengirim surat pertanyaan warga terkait rencana pembangunan pabrik semen ke tingkat DPR RI, Menteri Lingkungan Hidup dan Presiden. Sampai pada pertengahan tahun 2013, warga yang masih tetap tidak mendapat jawaban atas surat tersebut melakukan aksi di DPRD Rembang. Berawal dari aksi tersebut, warga berinisiatif untuk meminta bantuan hukum salah satunya dari LBH Semarang.

Ivan Wagner ${ }^{2}$ mengungkapkan bahwa kasus pembangunan pabrik semen di kawasan Pegunungan Kendeng, Rembang oleh PT. Semen Indonesia tidak bisa dipisahkan dari kasus pembangunan pabrik semen di Pati. Kasus yang terjadi pada tahun 2006 tersebut terjadi saat PT. Semen Indoensia yang dulu masih bernama PT. Semen Gresik ingin mendirikan pabrik semen di Pati. Namun, pihak PT.

${ }^{1}$ Ngatiban, warga Kendeng, Desa Tegaldowo Kecamatan Gunem Kabupaten Rembang, yang aktif bekerja sama dengan LBH Semarang dalam gerakan menolak pabrik semen di Kendeng.

2Ivan Wagner, anggota LBH Semarang dari divisi Sumber Daya Alam (SDA) yang menangani isu lingkungan.
Semen Gresik gagal mendirikan pabrik di Pati karena kasus yang diajukan di pengadilan berhasil dimenangkan oleh warga Pati.

Kegagalan untuk mendirikan pabrik dan area pertambangan bahan baku semen di Kabupaten Pati membuat PT. Semen Indonesia beralih ke Kabupaten Rembang tepatnya di kawasan Pegunungan Kendeng, Kabupaten Rembang. Seperti halnya yang terjadi di Kabupaten Pati, Pemerintah Daerah (Pemda) setempat memberikan izin penuh kepada PT. Semen Indonesia untuk mendirikan area pendirian pabrik dan area penambangan bahan baku semen. Bentuk yang diberikan oleh Pemda berupa dikeluarkannya berbagai izin yang diperlukan PT. Semen Indonesia. Salah satu perizinan yang disepakati adalah izin lingkungan kegiatan penambangan yang dituangkan dalam Surat Keputusan Gubernur Jawa Tengah Nomor 660.1/30 tahun 2016 (Wagner, 22 Des. 2017, wawancara).

Keresahan warga Kendeng dengan pendirian pabrik semen di kawasan sekitar mereka membuat mereka melakukan gerakan sosial perlawanan. Warga Kendeng menolak keras pendirian pabrik semen tersebut dengan pertimbangan dampak kerusakan alam yang berpotensi memperburuk keadaan lingkungan sekitarnya.

Permasalahan yang terjadi adalah ketika pihak pabrik semen tersebut berdalih bahwa mereka mendirikan pabrik telah sesuai dengan UU yang berlaku terkait AMDAL (Analisis Dampak Lingkungan). Padahal, warga sekitar kawasan pabrik semen merasa terkena dampak negatif akibat pembangunan pabrik 

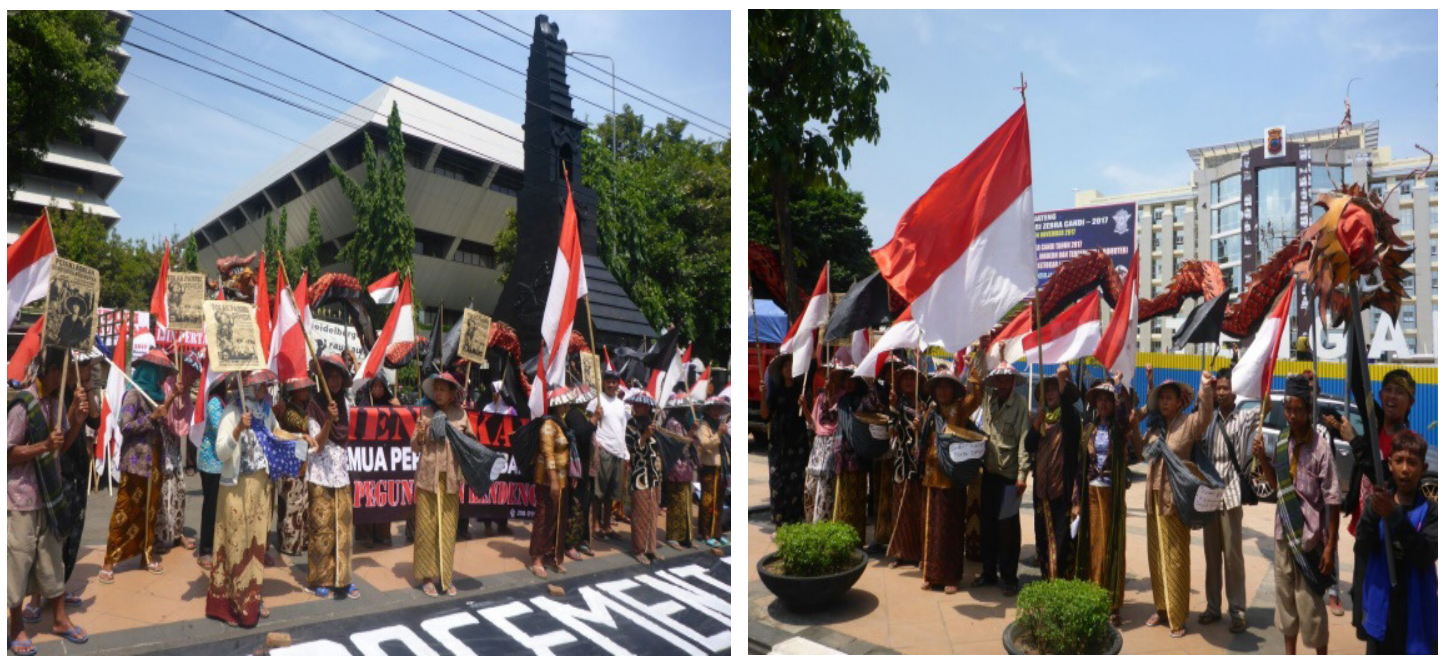

Gambar 1.

Aksi warga Kendeng dalam melakukan penolakan terhadap pembangunan pabrik semen di depan Kantor Gubernur Jawa Tengah. Sumber: Dokumen LBH Semarang.

semen. Warga juga khawatir akan kerusakan alam yang telah dan akan terjadi. Namun, karena keterbatasan pengetahuan warga terkait aturan AMDAL, warga tidak mampu melakukan penolakan terhadap pembangunan pabrik semen tersebut secara hukum (Ngatiban, 28 Jan. 2018, wawancara).

Zainal Arifin, ${ }^{3}$ juga mengungkapkan bahwa spesifikasi penyelenggaraan bantuan hukum, terutama dalam kasus penolakan pembangunan pabrik semen di kawasan Pegunungan Kendeng berupa gerakan sosial penegakkan keadilan hukum dan HAM. Gerakan tersebut dianggap sebagai penyuaraan masyarakat yang menganggap pabrik semen di kawasan Pegunungan Kendeng akan mengambil hak atas air, kelestarian lingkungan, dan merampas lahan masyarakat. Hal tersebut membuat ma-

${ }^{3}$ Zainal Arifin, Direktur LBH Semarang. syarakat menyadarkan sesamanya akan hak mereka yang harus dilindungi dan diperjuangkan (Arifin, 19 Des. 2017, wawancara).

Menanggapi kasus penolakan terhadap pembangunan pabrik semen tersebut, LBH Semarang memiliki beberapa peran, yakni:

\section{Pemberdayaan Masyarakat}

LBH Semarang melakukan pemberdayaan kepada masyarakat, terutama yang menjadi korban pelanggaran hukum. Dalam hal ini, masyarakat atau korban tidak hanya dibantu secara satu arah, namun juga memberdayakan masyarakat agar mampu membela hak diri sendiri maupun orang lain.

Prinsip untuk menangani semua kasus tentang pelanggaran HAM kemudian lebih khusus ketika ada isu mayor atau isu-isu yang sering muncul sehingga mempengaruhi mekanisme struktur LBH termasuk LBH 
Semarang, karena setiap LBH memiliki mekanisme struktur yang berbeda-beda. Yang pertama, melalui proses advokasi dalam jalur pengadilan, jalur politik, melakukan kampanye, audiensi, dan sebagainya. Sehingga masyarakat memahami proses penanganan kasusnya. Akhirnya masyarakat Kendeng lebih tahu tentang hukum lingkungan. Masyarakat akan diberi tahu proses AMDAL dan lain-lain, sehingga masyarakat tidak dapat ditipu lagi. Maka melalui BHS ini mampu memberdayakan masyarakat.

\section{Advokasi}

LBH Semarang membantu masyakarat melalui advokasi. Masyarakat dituntut untuk dapat memahami hukum yang ada Pola advokasi LBH Semarang, jika LBH konvensional hanya melakukan pembantuan di pengadilan sebagai lawyer atau pengacara, tetapi LBH Semarang lebih menekankan analisis kasus tersebut, ketika terjadi ketimpangan struktur maka pendampingan akan dilakukan. Begitu pun pada penanganan kasus pelanggaran yang dilakukan oleh PT. Semen Indonesia terhadap warga Kendeng, LBH Semarang melihat adanya ketimpangan struktur antara pemerintah melawan rakyat biasa. Sehingga LBH Semarang mengambil tindakan dalam membantu menegakkan keadilan kasus tersebut.

\section{Pendampingan Pendidikan Hukum}

Proses pendampingan dilakukan dengan melakukan diskusi dengan warga Kendeng. Bentuk pendampingan ini bertujuan agar warga dan LBH Semarang melakukan gerakan sosial bersama-sama. Sehingga warga dapat mengetahui proses hukum yang dihadapi dan mengikuti proses persidangan tersebut. Dengan cara tersebut, masyarakat diharapkan mampu mengatasi permasalahan serupa secara mandiri (Arifin, 19 Desember 2017, wawancara).

Peran LBH Semarang mendampingi masyarakat Kendeng dalam gerakan penolakan pendirian pabrik semen pada tahun 2012 yang kemudian gerakan sosial tersebut mulai intensif dilakukan pada tahun 2014. LBH Semarang dalam perannya memberikan bantuan kepada masyarakat untuk melakukan aksi-aksi ataupun melawan ketidakadilan hukum dan pelanggaran HAM, berusaha mewujudkan hubungan yang baik antara pihak LBH Semarang dengan warga maupun pihak lain yang terkait, dijabarkan sebagai berikut:

\section{Menjalin Kerjasama dengan Berbagai Pihak}

Gerakan sosial oleh warga Kendeng bermula ketika mereka mulai menjalin komunikasi untuk melakukan gerakan sosial bersama Jaringan Masyarakat Peduli Pegunungan Kendeng (JM-PPK) untuk menolak pembangunan pabrik semen di kawasan Pegunungan Kendeng. Sejak pertemuannya dengan JM-PPK diikuti juga perkenalan warga dengan Lembaga Bantuan Hukum (LBH) Semarang yang sebelumnya juga membantu gerakan warga terhadap kasus yang serupa yaitu bantuan hukum serta pendampingan terhadap masyarakat penolak pembangunan pabrik semen di Pati. 
LBH Semarang bekerjasama dengan organisasi sosial besar seperti WALHI dan LBH Jakarta dalam pendampingan hukum di pengadilan maupun di luar pengadilan. Kerja sama tersebut dilakukan mulai dari mencari advokat dalam pembelaan warga Kendeng di pengadilan maupun pendampingan dalam setiap aksi warga sebagai bentuk penolakannya.

\section{Membangun Kepercayaan dengan Warga}

LBH Semarang berusaha menjalin komunikasi dan hubungan baik dengan warga Rembang untuk membangun kepercayaan dalam melancarkan tujuan bersama-sama yakni menyelesaikan permasalahan tentang pembangunan pabrik semen tersebut (Wagner, 22 Desember 2017, wawancara).

Hal tersebut juga ditambahkan oleh Zainal Arifin yang mengungkapkan bahwa konflik yang harus dihindari adalah konflik kepentingan. Pembangunan pabrik semen di kawasan Pegunungan Kendeng tersebut juga memisahkan masyarakat menjadi dua sisi yaitu pro dan kontra. Masyarakat yang setuju, beranggapan bahwa dengan berdirinya pabrik semen tersebut asalkan pihak PT. Semen Indonesia mampu memberikan ganti rugi secara materi yang sesuai dengan keinginan mereka.

Namun, disisi lain kita harus memperhatikan bagaimana dampak yang ditimbulkan. Masyarakat yang tidak setuju dengan pembangunan pabrik di kawasan Pegunungan Kendeng berpendapat bahwa proyek tersebut tidak hanya berimbas pada sekelompok orang yang ada disekitarnya saja melainkan juga berdampak pada hilangnya tempat penge- tahuan terkait lingkungan yang lestari bagi anak cucu mereka dan hilangnya tempat para perempuan untuk mencari sumber makanan.

Hal tersebut membuat komunikasi menjadi penting guna menyatukan persepsi antara masyarakat dengan pihak LBH Semarang untuk mencapai tujuan tersebut. Hal tersebut dilakukan agar tidak terjadi konflik sosial dalam masyarakat.

Jadi, segala bentuk aksi lapangan berasal dari inisiatif warga sendiri mulai dari mempersiapkan peralatan aksi seperti spanduk, dan lain-lain. Sedangkan LBH membantu dalam segi administratif dan pendidikan terkait dengan aturan hukum yang berlaku serta berusaha mendampingi semua kebutuhan dalam pembelaan hukum di pengadilan. Selain itu, warga juga mendapat bantuan dari berbagai pihak jaringan lain salah satunya membangun jaringan rekan-rekan LBH dari Jakarta untuk aksi gerakan demo menolak pabrik semen (Ngatiban, 28 Jan. 2018, wawancara).

\section{Hambatan dan Tantangan dalam Gerakan Sosial Menolak Pembangunan Pabrik Semen di Kawasan Pegunungan Kendeng}

Suatu negara hukum (rechtstaat) baru tercipta apabila terdapat pengakuan terhadap demokrasi dan hak asasi manusia. Indonesia sebagai Negara yang telah menyatakan diri untuk menjunjung tinggi Hak Asasi Manusia (bahkan diakui dalam dasar negara) telah memberikan perlindungan khusus bagi penerus bangsa ini melalui Undang-Undang Nomor 39 tahun 1999 tentang Hak Asasi Manusia (Qomar, 2016: 15). 
Ivan Wagner mengungkapkan, kasus pendirian pabrik semen di kawasan Pegunungan Kendeng merupakan salah satu kasus pelanggaran HAM yang cukup rumit. LBH Semarang sebagai lembaga bantuan hukum struktural yang menangani kasus pelanggaran HAM ikut serta dalam penanganan polemik yang terjadi tersebut. Bentuk pelanggaran HAM tersebut dapat dibuktikan dari berbagai rentetan kasus yang dialami oleh warga Kendeng dalam gerakan sosial menolak pembangunan pabrik semen di kawasan Pegunungan Kendeng antara lain:

\section{Kebijakan Pemerintah yang Sewenang-wenang}

PT. Semen Indonesia sebagai milik BUMN, membuat warga Kendeng juga harus berhadapan dengan gubernur yang masa itu masih dijabat oleh Bibit Waluyo (saat ini dijabat oleh Ganjar Pranowo). Kesewenangan pemerintah dapat dilihat ketika LBH Semarang bersama warga Kendeng yang telah berhasil memenangkan kasus di pengadilan yang menandakan PT. Semen Indonesia harus berhenti beroperasi di kawasan Pegunungan Kendeng. Namun, dengan mudahnya Ganjar Pranowo, selaku Gubernur Jawa Tengah saat ini memutarbalikkan fakta yang membuat Mahkamah Agung memberikan izin PT. Semen Indonesia beroperasi di wilayah tersebut (Wagner, 22 Desember 2017, wawancara).

\section{Adanya Intimidasi}

Bentuk intimidasi ini yang diterima oleh warga Kendeng berawal dari pemblokiran jalan yang dilakukan oleh warga untuk menghalangi truk-truk dan kendaraan besar milik PT. Semen Indonesia yang ingin melakukan pembangunan pabrik semen di kawasan Pegunungan Kendeng. Warga melakukan pemblokiran jalan dengan alasan bahwa warga belum mendapat pemberitahuan atau izin dari pihak PT. Semen Indonesia untuk mulai melakukan proyek pembangunan di wilayah tersebut.

Namun, aksi tersebut justru membuat warga mendapat tanggapan buruk dari pihak PT. Semen Indonesia. Mereka diintimidasi dalam bentuk pengusiran paksa, penangkapan, bahkan mengalami kekerasan fisik seperti ditendang, dan dipukul oleh pihak polisi dan TNI. Selain itu, tenda-tenda milik warga pemblokiran jalan yang berada di depan pintu masuk proyek pembangunan pabrik dibakar oleh petugas. Ancaman dari orang yang tak dikenal juga dialami oleh warga bersama perwakilan LBH Semarang yang menuju perjalanan ke Semarang untuk melakukan audiensi dengan pihak terkait (Wagner, 22 Desember 2017, wawancara).

\section{Kriminalisasi}

Salah satu bentuk kriminalisasi terjadi pada Joko Prianto. Ia warga Rembang, pejuang gerakan sosial penolakan pembangunan pabrik semen oleh PT. Semen Indonesia di kawasan Pegunungan Kendeng. Ia dilaporkan ke pihak kepolisian oleh PT. Semen Indonesia dengan tuduhan memalsukan surat. Tuduhan tersebut dianggap tanpa bukti, karena surat yang dilaporkan palsu tersebut sudah disahkan oleh Mahkamah Agung. Namun, ia masih ditetapkan sebagai tersangka dalam proses pra-peradilan. Meskipun Joko Prianto sebagai 
pejuang lingkungan telah dilindungi oleh pasal 66 UU PPLH, kriminalisasi terhadapnya tetap berlanjut. Terlihat bagaimana hukum ditegakkan dengan melarang hukum itu sendiri (LBH Semarang, instagram @lbhsemarang, 28 Desember 2017).

\section{Masalah Biaya}

Biaya yang digunakan dalam aksi warga, dilakukan dengan swadaya oleh masingmasing warga secara sukarela. Setiap biaya yang dikeluarkan murni dari swadaya masyarakat yang mendukung penolakan pabrik, misalnya melalui usaha yang dilakukan oleh ibu-ibu warga Desa Tegaldowo dengan mengadakan arisan dan menyisihkan sebagian uangnya untuk disumbangkan demi berjalannya aksi tersebut. Namun, warga mengakui hasil swadaya tersebut menjadi masalah dalam melakukan aksi penolakan pabrik semen seperti biaya transportasi dan kebutuhan aksi yang lain (Ngatiban, 28 Januari 2018, wawancara).

\section{Perbedaan Pendapat Antar Warga}

Masalah tersebut terjadi karena tidak semua warga menolak pabrik semen. Sebagian warga yang ikut bekerja di pabrik tersebut mendukung pembangunan pabrik semen karena mereka merasa diuntungkan dengan adanya pabrik semen. Beberapa LSM juga berpihak pada pabrik semen. Perbedaan pendapat tersebut tentunya menjadi masalah penyelesaian aksi penolakan pabrik semen di kawasan Pegunungan Kendeng (Ngatiban, 28 Januari 2018, wawancara).

\section{Kesimpulan}

LBH Semarang sebagai lembaga bantuan hukum yang berperan sebagai gerakan sosil untuk penegakan keadilan hukum dan hak asasi manusia menggunakan pendekatan Bantuan Hukum Struktural (BHS) yang tidak dipakai oleh kebanyakan LBH lainnya di Indonesia. Bantuan hukum struktural adalah satu metode bantuan hukum yang mendasarkan pada pembacaan situasi struktural baik itu politik, ekonomi maupun budaya dan sosial. Selain itu dalam menangani kasus pelanggaran hukum, terutama kasus Kendeng, LBH Semarang melakukan berbagai aksi langsung maupun tidak langsung kepada berbagai pihak.

Kasus pendirian pabrik semen di kawasan Pegunungan Kendeng merupakan salah satu kasus pelanggaran HAM yang cukup rumit. LBH Semarang sebagai lembaga bantuan hukum struktural yang menangani kasus pelanggaran HAM ikut serta dalam penanganan polemik yang terjadi terkait penolakan pembangunan pabrik semen di kawasan Pegunungan Kendeng tersebut. Bentuk pelanggaran HAM tersebut dapat dibuktikan dari berbagai rentetan kasus dialami oleh warga Kendeng dalam gerakan sosial menolak pembangunan pabrik semen di kawasan Pegunungan Kendeng.]

\section{Daftar Pustaka}

Arrasjid, Chainur. 2000. Dasar-dasar Ilmu Hukum. Jakarta: Sinar Grafika.

Fitri, Annisa Innal dan Idil Akbar. 2017. "Gerakan Sosial Perempuan Ekofeminisme di Pegunungan Kendeng 
Provinsi Jawa Tengah Melawan Pembangunan Tambang Semen." CosmoGov 3(1):83. Diakses 10 Desember 2017 (http://jurnal.unpad.ac.id/cosmogov/ article/view/12634).

Hakim, Abdul and Mulyana Kusuma. 1981. Beberapa Pemikiran Mengenai Bantuan Hukum: Ke Arah Bantuan Hukum Struktural. Bandung: Alumni.

LBH Semarang. n.d. "Kerja Kami." LBH Semarang. Diakses 20 Desember 2017 (http://lbhsemarang.or.id/\# kerjakami).

LBH Semarang, instagram, @lbhsemarang, 28 Desember 2017.

Nasution, Adnan Buyung. 2007. Bantuan Hukum di Indonesia. Jakarta: LP3ES.

Qomar, Nurul. 2016. Hak Asasi Manusia dalam Negara Hukum Demokrasi. Jakarta: Sinar Grafika.

Sinduprabowo, Muhammad. 2017. "Resolusi Konflik Pendirian Pabrik Semen Antara PT. Sahabat Mulia Sakti dengan Masyarakat di Kabupaten Pati Tahun 2015: Studi Kasus Peran Jaringan Masyarakat Peduli Pegunungan Kendeng." Universitas Muhammadiyah Yogyakarta.
Diakses pada 10 Desember 2017 http://repository.umy.ac.id/bitstream /handle/123456789/12114/10\%20N askah\%20Publikasi.pdf?sequence $=10$ \&isAllowed=y.

Sufyani, Ahmad. 2015. "Gerakan Sosial Masyarakat Pegunungan Kendeng Utara Melawan Pembangunan Pabrik Semen di Kabupaten Rembang." Universitas Airlangga Surabaya, Surabaya. Diperoleh dari (http://journal.unair.ac.id/download-fullpaperskmntse445f6d167full.pdf).

Sugiyono. 2005. Memahami Penelitian Kualitatif. Bandung: Alfabeta.

Suharko, -. 2006. "Gerakan Sosial Baru di Indonesia: Repertoar Gerakan Petani." Jurnal Ilmu Sosial dan Ilmu Politik 10(1):1-34. Diakses 23 Januari 2018 (https://jurnal.ugm.ac.id/jsp/ article/view/11020).

Triwibowo, Darmawan. 2006. Gerakan Sosial: Wahana Civil Society bagi Demokratisasi. Jakarta: LP3ES.

Wahyudi. 2005. Formasi dan Struktur Gerakan Sosial Petani. Malang: UMM Press. 